\title{
Inside Taiwan's Sunflower Movement: Twenty-Four Days in a Student-Occupied Parliament, and the Future of the Region
}

\section{IAN ROWEN}

« $\mathrm{C}$ Ay Goodbye to Taiwan, "wrote political scientist John Mearsheimer in a widely read Sarticle in the March-April 2014 issue of The National Interest. ${ }^{1}$ Threatened by China's rising economic might and abandoned by a weakening United States, one of Asia's most vibrant democracies was facing, in his "realist" analysis, an almost inevitable annexation via economic if not military force. "Time," he wrote, "is running out for the little island coveted by its gigantic, growing neighbor." But only days after publication, on March 18, activists and armchair analysts alike said hello to a new reality.

That evening, the assembly hall of Taiwan's Legislative Yuan was stormed by a motley crew led by students from the "Black Island Nation Youth," a loosely organized student political action committee formed the previous year. The several hundred occupiers repelled police efforts to eject them, escorted out the few officers on duty, and barricaded the doors with seats tied together with rope. None of them expected that the occupation, later known as the 318 or Sunflower Movement, would last twenty-four days, spawn the biggest pro-democracy protest rally in the island's history, reframe popular discourse about Taiwan's political and social trajectory, precipitate the midterm electoral defeat of the ruling party, and prefigure unprecedented protest in nearby Hong Kong. ${ }^{2}$

The direct trigger for the protest was the perceived flouting of parliamentary due process by Taiwan's ruling party, the Chinese Nationalist Party (Kuomintang or KMT), in its efforts to push a major trade deal with China through the legislature. Indeed, on Monday, March 17, legislators from the KMT reneged on a June 2013 agreement with the opposition party, the Democratic Progressive Party (DPP), for an item-by-item review of the Cross-Strait Services Trade Agreement (CSSTA). Instead of conducting the promised review, KMT legislator Chang Ching-Chung, the convener of the committee, unilaterally declared that the review period had already ended and that the bill would be submitted to a plenary session on March 21 . Had this legally questionable process not been interrupted, it was all but certain that the KMT-dominated legislature would have

\footnotetext{
Ian Rowen (ian.rowen@colorado.edu) is PhD Candidate in Geography at the University of Colorado, Boulder. ${ }^{1}$ John J. Mearsheimer, "Say Goodbye to Taiwan," The National Interest, March-April 2014, http:// nationalinterest.org/article/say-goodbye-taiwan-9931 (accessed November 14, 2014).

${ }^{2}$ Having entered the Legislative Yuan on March 19 and stayed inside and around the building for most of the occupation, this reflection and the rest of the article is based on a mix of first-hand participant-observation, interviews, and analysis. Coming from an embedded researcher, this account more reflects voices from inside the movement than those of its outside critics.
} 
passed the bill for a signature from President Ma Ying-jeou, who had championed its passage. ${ }^{3}$

The CSSTA was negotiated and signed behind closed doors in Shanghai on July 21, 2013, by representatives from Taiwan's quasi-state agency, the Straits Exchange Foundation, and its Chinese counterpart, the Association for Relations Across the Taiwan Strait. ${ }^{4}$ The CSSTA would open eighty sectors of China's economy to Taiwanese investment, and sixty-four sectors of Taiwan's economy to Chinese investment, including hotels, tourism, printing, and medical services. The CSSTA followed the Economic Cooperation Framework Agreement (ECFA), a broad agreement for increased economic integration between Taiwan and China, signed in 2009. Both the ECFA and the CSSTA were touted by the Ma administration as major boons for Taiwan's economy, although the government's own Chung Hua Institute for Economic Research estimated the latter would bring only a $0.025-0.034$ percent increase in Taiwan's annual gross domestic product (GDP).

Taiwan's service industry accounts for roughly 70 percent of its GDP. Anti-CSSTA activists decried the treaty's secretive negotiation as undemocratic and under-the table (literally, heixiang for "black box"), and expressed particular concern for the impact that greater Chinese penetration in Taiwan's economy would have on the island's small- and medium-sized businesses, media culture, and freedom of expression. ${ }^{5}$ Advocates of Taiwanese sovereignty and democracy argued that this trade bill had ominous implications for national security and self-determination. Others suggested that a president who had been polled months earlier at an astonishingly low 9 percent approval rating had no mandate to push for such major legislation. Throughout, Ma has been the prime personal target of discontent, as not only the president but also the chairman of the KMT, able to use party discipline mechanisms to force legislators to cast approval votes for the bill.

In early March, fearing that the KMT's legislative majority would guarantee the passage of the bill, representatives from various sectors of Taiwan's civil society, including students and nongovernmental organization (NGO) leaders, staged regular planning meetings under the umbrella of a coalition group, the Defend Taiwan Democracy Platform. As March 18 drew near, the Platform's conveners planned a series of press conferences and rallies in front of the Legislative Yuan. This approach was deemed insufficient by several participants in the meeting, who called for more aggressive direct action. This suggestion was not vetoed, but with the nearly fifty people present in these planning meetings and the possibility of leaks, conveners asked that such planning happen off the premises. "We told them we wouldn't object, but they should talk about it somewhere

\footnotetext{
${ }^{3}$ For an account of the complicated legislative machinations, see J. Michael Cole, "Taiwanese Occupy Legislature over China Pact," The Diplomat, March 20, 2014, http://thediplomat.com/ 2014/03/taiwanese-occupy-legislature-over-china-pact/ (accessed October 23, 2014).

${ }^{4}$ As Taiwan and China do not recognize each other's sovereignty, such quasi-state, quasi-private institutions are used for formal negotiations.

${ }^{5}$ For more details about the economics of the CSSTA, see JoAnn Fan, "The Economics of the Cross-Strait Services Agreement," The Diplomat, April 18, 2014, http://thediplomat.com/2014/ 04/the-economics-of-the-cross-strait-services-agreement/ (accessed October 23, 2014).
} 
else," said Ms. Lu, a lawyer and academic present in the final meeting before the occupation. ${ }^{6}$

The campaign to enter the building began at the next night's rally. Entrance routes to the buildings had earlier been scouted by Black Island-affiliated students, who later attended the rally and shared directions to climb over walls or through underpasses by word of mouth or smartphone messaging. Like the near-passage of the CSSTA itself, the sudden plan to storm the building caught some protesters unaware. Said Mr. Lin, a sixty-six-year-old retired electronics importer who joined the first wave of the occupation and ended up heading waste management throughout the occupation, "I was just at the rally to show support and ended up getting swept in with the crowd." A gate and window were broken to clear a pathway inside, but other property damage was kept to a minimum, with student leaders continually reminding the crowds not to vandalize.

The few policemen inside the complex were quickly overwhelmed, and a later directive by Premier Jiang Yi-huah to send in riot police was ignored by Wang Jin-pyng, the long-serving speaker of the Legislative Yuan. Wang, a KMT heavyweight with a tense relationship with President Ma Ying-jeou, was to be a key behind-the-scenes player in the occupation. As the man legally responsible for the Legislative Yuan's day-to-day operations, Wang snubbed Ma's call for an emergency meeting the next day to end the occupation, and soon promised that protesters would not be removed by force.

Tensions between Ma and Wang, two of the KMT's most powerful politicians, go back several election cycles and had worsened considerably in the previous year. In September 2013, Ma accused Wang of influence peddling and attempted to remove him from the KMT. As an unelected party-list legislator, a loss of party membership would have forced Wang from his position as Legislative Yuan speaker. Wang filed a counter-suit which still remained unresolved when the protest began, keeping the Legislative Yuan in a "state of temporary anarchy," as Ms. Lu, the activist lawyer-academic, put it. However, on March 19, just one day after the protest began, and almost certainly for unrelated reasons, Wang received a legal verdict maintaining his KMT membership. With it, he maintained his control over the Legislative Yuan. Ma's overreach, not just with the CSSTA but within his own party, immediately seemed a disastrous tactical error, allowing an unlikely tacit alliance between Wang and the occupiers, to the chagrin of Ma's wing of the KMT.

By the time I entered the Legislative Yuan on March 19, the central building was already loosely guarded by an emergent system of student security teams and patiently confused police, supported by sympathetic opposition legislators still afforded the legal right to bring in guests. The DPP legislators who showed up first to ostensibly defend occupiers against possible police violence and later to begin serving in door-guarding shifts, including Hsiao Bi-khim and Yu Mei-nu, were themselves veterans of past Taiwanese democratic and feminist movements. Usually reading magazines and showing signs of fatigue, the legislators did little but help people come and go as students needed. Members of the key civic groups that soon entered, including ad hoc volunteer medical and legal teams, as well as food supply and technical support crews led by students, were regularly waved in by legislators, as was I on several passes. Despite

${ }^{6}$ This name has been changed. 
numerous attempts to paint the occupation as a DPP plot, the opposition party's passive role was illustrated by a (probably apocryphal) joke: a certain well-known student supposedly asked party list legislator Tuan Yi-Kang to buy him a pack of cigarettes on his way back for a door guard shift. The few other DPP politicians inside the building on the first week came in to take personal photos or escort journalists, and then made a rapid exit as Taiwan's paparazzi media chased after them. Party officials also quickly passed a resolution forbidding the display of any DPP signs or logos within the occupation zone. ${ }^{7}$

The broad geopolitical implications of a protest against ostensible KMT collusion with China were not lost on 1989 Tiananmen Square protest leaders Wang Dan and Wu'er Kaixi, both long-based in Taiwan, who briefly entered the Legislative Yuan on March 19 to announce their support for the students. Less high-profile but no less active inside the Legislative Yuan were several locally enrolled students from Hong Kong and even mainland China, who had entered the building with their classmates. "Yes, I'm not supposed to be here, but I'm curious what this is all about-this couldn't happen in China!" said BB, a finance student. ${ }^{8}$

Never mind China - a sustained civil occupation of a key government building is hard to imagine in most countries, and points simultaneously and paradoxically to Taiwan's high degrees of both political fractiousness and social civility. On March 20, King $\mathrm{Pu}$-tsung, a long-time Ma aide, returning from his role as chief U.S. envoy to take up a powerful position as the head of the National Security Council, told the local television press that "a democratic society ruled by the law does not allow anyone to occupy parliament or damage public properties through violence or forces. It is something that would not be allowed in the US." 9 The following morning in the occupied Legislative Yuan, Lee Chun-Ta, a philosophy student at Soochow University, read King's newspaper quote over the loudspeakers and gamely commented that the Wisconsin State Capitol had in fact recently been occupied by student protesters. They had not, however, taken over the assembly chambers. Even if King overstated his case by repeatedly characterizing protesters as violent, he was, for better or worse, almost certainly correct that such a long-term occupation would not be allowed within an equivalent space in the U.S. Congress.

Apart from such allegations of "hooliganism," another common criticism was that the protesters were anti-trade, anti-globalization, or unclear on the contents of the CSSTA. For example, academic Pan Hua-sheng argued that "the movement can be described as anti-globalization, formed by a number of 'China skeptics' who have used a lazy

${ }^{7}$ Throughout the occupation, volleys of text and Facebook messages were sent in attempts to link Black Island's most visible spokespeople, Chen Wei-ting and Lin Fei-fan, to the DPP's past presidential candidate, Tsai Ying-wen, a legal scholar and former chair of the Mainland Affairs Council. Pro-KMT pundits repeated a similar line on television talk shows. Indeed, both Chen and Lin had volunteered for local youth committees of Tsai's 2012 campaign, but there is no evidence that Tsai was involved in initiating the occupation.

${ }^{8}$ This name has been changed.

9"King Pu-tsung's Behind-The-Scenes Role in China Pact Protest," Want China Times, March 31, 2014, http://www.wantchinatimes.com/news-subclass-cnt.aspx?id=20140331000042\&cid=1601 (accessed November 14, 2014). 
packaged description of the pact so that the movement can trigger huge momentum during a short period of time." 10

Further complicating the controversy over the pact was the earlier ambiguous stance of the DPP, which, caught between the oft-clashing interests of cross-strait capital and their grassroots electoral calculus, has long struggled to build an intra-party consensus on China issues. While the DPP had demanded a thorough review of the CSSTA, the mainstream of the party had declined to take a strong position against the treaty. Protest supporters responded to such critiques by stressing that they were not against trade or globalization per se, but were opposed to opaque agreements advanced by an administration without a popular mandate. They also maintained that activists were in fact restoring democracy by augmenting a DPP and a constitutional system too structurally weak to ensure legislative due process on their own. ${ }^{11}$

Despite the media's initial focus on minor property damage, domestic public opinion quickly swung in favor of the movement's call for the CSSTA to be sent back for review, with a majority of television poll respondents expressing disapproval of government conduct and support for the students' demands. ${ }^{12}$ The courtyard and streets outside the Legislative Yuan soon swelled with increasingly sophisticated participation from new student and civic groups, including food distribution networks, blankets and raincoats for nights with cold and wet weather, mobile recharging and Wi-Fi access centers, and free speech zones. Professors from across Taiwan held outdoor classes in the streets surrounding the Legislature, and a tent city with distinctive neighborhoods began to coalesce.

After a local florist donated a case of fresh sunflowers to the front lines of the protest-later said to represent the illumination of the "black box"- the growing movement had found its symbol. While some activists were quick to embrace the flower, handing them out both inside and outside the building, others dissented. "We don't need some cute flower to represent us," said June, a third-year politics major, garbed in all black, who had joined the nascent security team. ${ }^{13}$

\section{The Soil that Sprouted the Sunflowers}

While the Sunflower occupation of the Legislative Yuan quickly dominated newspaper headlines and television news cycles, it was not the first protest against the CSSTA. While these earlier, smaller actions had largely been ignored, they were spearheaded by students and civil activists who first gained notice in the anti-Media Monopoly campaign of 2012 and the short-lived Wild Strawberry Movement of 2008. These movements shared not only members and tactics with the Sunflowers, but also deep misgivings

\footnotetext{
${ }^{10}$ Pan Hua-sheng, "KMT Should Continue to Push Economic Benefits of Trade Pacts," Want China Times, April 3, 2014, http://www.wantchinatimes.com/news-subclass-cnt.aspx?id=201404030000 23\&cid=1703 (accessed November 6, 2014).

${ }^{11}$ See Taiwan-based political scientist Nathan Batto's discussion, "Can Extra-Democratic Tactics Be Democratic?," Frozen Garlic, March 21, 2014, http://frozengarlic.wordpress.com/2014/03/21/ can-extra-democratic-tactics-be-democratic/ (accessed November 6, 2014).

${ }^{12}$ This result was reported even by TVBS, a news station usually described as mildly pro-KMT. See TVBS, "CSSTA and Student Occupation Poll," March 21, 2014, http:/home.tvbs.com.tw/static/ FILE_DB/PCH/201403/20140321224523298.pdf (accessed November 14, 2014).

${ }^{13}$ This name has been changed.
} 
about the political and economic relationships that the Ma administration and its allied business interests were forging with China.

The Wild Strawberries were a response to the KMT's handling of the visit by China's representative Chen Yunlin in November 2008, in which symbols not only of Taiwanese national identity, but even of the Republic of China, the official name of Taiwan's state apparatus, were forcibly removed so as not to offend Chen. Students complained that their free speech rights were being trampled to placate an authoritarian neighbor bent on annexation and called for an apology from the president and the police. They also demanded the abolition of the Assembly and Parades Act, a martial law-era relic which has long been used to suppress popular protest, and was later invoked against Sunflower affiliates. The Wild Strawberries were so-named both to invoke a connection with the Wild Lily Student Movement of 1990, which successfully pressured then-president Lee Teng-Hui to accelerate democratic institutional reforms, and to subvert a popular stereotype of Taiwanese millennials as "strawberries" — sweet and beautiful but weak and easily bruised. Ultimately, the movement fizzled out after a small, several month occupation of Liberty Square, the site of the earlier Wild Lily Movement and still home to a monument to the late KMT dictator, Chiang Kai-shek.

The Anti-Media Monopoly Campaign, which followed in 2012, included Wild Strawberry activists and attracted a far wider base of support. ${ }^{14}$ The campaign was a response to the attempt of the Want Want China Times group, a food and media conglomerate with extensive interests in China and a clear pro-China editorial slant, to gain a controlling share in the Apple Daily and Next Media group, two of the few remaining major media outlets to remain critical of China. The Anti-Media Monopoly campaign successfully blocked Want Want's purchase. With its sophisticated social media campaigns and cooperation with Taiwan's civil-minded academic sector, the Anti-Media Monopoly campaign perhaps served as a practice run for the decentralized, networked forms of protest later utilized by the Sunflowers. It also made media darlings of its convener, Lin Fei-fan, a politics graduate student at National Taiwan University (NTU); Chen Wei-ting, a sociology graduate student at National Tsinghua University; and Huang Kuo-chang, a legal scholar at Academia Sinica, who resurfaced as the most visible spokespeople of the Sunflower Movement.

\section{OcCUPIED DaYs AND Nights}

Emboldened by popular support and joined by scholars and civil activists, occupation spokespeople soon expanded their demands. With legal scholar Huang Kuo-chang, lawyer-activist Lai Chung-chiang, and representatives from the Taiwan Association for Human Rights and other NGOs taking increasingly assertive strategic and logistical roles, to the dismay of some more radical students who complained of increasing

\footnotetext{
${ }^{14}$ For analysis of the campaign, see Taiwan specialist Mark Harrison's account, "The Anti-Media Monopoly Movement in Taiwan," The China Story, December 20, 2012, http://www.thechinast ory.org/2012/12/the-anti-media-monopoly-movement-\%E5\%8F\%8D\%E5\%AA\%92\%E9\%AB\% 94\%E5\%A3\%9F\%E6\%96\%B7\%E9\%81\%8B\%E5\%8B\%95-in-taiwan/ (accessed October 23, 2014).
} 
marginalization, the demand for a review of the CSSTA instead became a demand for the government to draft and implement a legislative mechanism for the review of cross-strait agreements. Huang argued that as current law, based on the Republic of China constitution adopted in 1949, still treats the "Mainland Area" and "Taiwan Area" as separate jurisdictions within the same country, there is no proper legal procedure for review of a treaty-type agreement like the CSSTA. He maintained that short of drafting a new constitution - a very tall order - a supervisory mechanism would at least provide more public oversight for the drafting and passage of cross-strait agreements.

Another Sunflower demand was a public audience with President Ma, who instead sent Premier Jiang Yi-huah as his representative for a televised public meeting with student spokesperson Lin Fei-fan on the street in front of the Legislative Yuan on March 22. During a tense ten-minute stand-off, after Jiang affirmed that he was unauthorized to accede to protester demands, Lin thanked Jiang for his visit and sent him away.

The lack of a personal response from the president led to an increasingly desperate mood inside the Legislative Yuan. Late that night, as some students attempted to gratefully sleep in the fresh sleeping bags that had just been donated through NGOs and handed out by an ad hoc supply team, Peter, a Chinese language education student from Tainan, complained to me, "If we don't take more radical steps immediately, this will all have been pointless." 15 He said he had attempted to voice his opinion to the increasingly insulated leadership core, who he complained seemed uninterested in input from people they did not already know.

Although Peter may have felt his voice was being ignored, enough people shared his sentiment to take action. On Sunday night, March 23, a group of students and activists stormed the Executive Yuan, Taiwan's cabinet building. Their connection to and coordination with the occupation's core leadership was unclear even to people on the front lines of the campaign. "I thought it was being led by Black Island, but now I'm not sure," said Yi-shan, an NTU law student and Wild Strawberry veteran, immediately after being carried out of the building by riot police. A kilometer away, within the Legislative Yuan, Chen Wei-ting expressed solidarity with activists at the Executive Yuan but claimed that they were operating independently. Whatever the case, what is clear is that, as on the night of March 18, many of the participants joined in an ad hoc fashion, loosely coordinated via dynamic social media and mobile messaging platforms.

While the Executive Yuan campaign was a startling, risky, and arguably poorly planned move, its quick and violent suppression by riot police under the order of Premier Jiang elevated the movement to a national crisis. Over 150 activists were injured and many hospitalized. A student leader of the campaign, Dennis Wei, was arrested and ultimately released from detention, only to face charges later. Despite the failure to hold the building, indelible images of bloodied students may have played into the protesters hands by raising public sympathy. "Those are our kids and even if they shouldn't be occupying government buildings indefinitely, they shouldn't be hurt," said a civil servant from the Tourism Bureau, reflecting a common opinion. ${ }^{16}$ Though the Executive

\footnotetext{
${ }^{15}$ This name has been changed.

${ }^{16}$ Interview with author, March 24, 2014.
} 
Yuan campaign ended with mixed results for both sides, the occupation of the Legislative Yuan was to continue for several more weeks.

\section{The Legislative Yuan Reterritorialized as the Office of an Ad Hoc Opposition}

While the first days inside the occupied Legislative Yuan were chaotic, with police eviction attempts, power and water cuts, and food shortages, the space soon regularized. While few of the alternately exhausted and elated occupiers fully trusted Speaker Wang Jin-Pyng's March 20 promise not to remove them by force, increasing public support for the action, improvised improvements to the air circulation system and other building infrastructure, and an awareness that the space may not be theirs forever led occupiers to settle into more regular workflows and ad hoc teams $(z u)$. By the second week, the space was increasingly bureaucratic and efficient, arguably more so than during regular sessions, which have long been internationally notorious for televised fistfights and shouting matches between legislators.

Enabling all of this to take place was a growing Security (jiucha) team, which had designated crews to guard each of the Legislative Yuan's barricaded inner and outer doors. With police guarding the building, permission to enter the outer doors could only be granted by sitting legislators who did not recognize most people attempting to enter and would follow the lead of the student security crew. Volunteer security teams were trained to inspect bags for weapons, tear gas, or other items that might be used to endanger people inside the building. They also attempted to filter out plainclothes policemen, who, according to security team leader Huang Yen-ju, a social worker, continuously attempted to infiltrate the building. The tense interaction between police and occupiers grew increasingly relaxed after Speaker Wang's announcement that occupiers would not be removed by force, and with increased volunteer training and courtesy. Upstairs on the second floor of the building, where sensitive strategy and work team meetings took place, the internal security teams were a much more freewheeling affair. Continental philosophy study sessions, sketching workshops, and even massage circles kept these students awake during the late hours.

In the increasingly relaxed atmosphere, other work teams with specific areas and tasks consolidated quickly. Behind the speaker's podium was the information team (zixunzu), broadly responsible for day-to-day control of the entire site. To their left was the medical station, continually staffed by rotating crews of volunteer off-duty Western and traditional Chinese physicians, nurses, psychologists, and occupational therapists. Many of these volunteers also conducted spot temperature checks and hand sanitizing rounds throughout the building.

To the right of the podium was the media team, largely staffed by NTU Law School students, and including translators and activist-journalists who produced multilingual copy for "official" and affiliated movement Facebook pages, Twitter feeds, and e-mail lists. In front of the podium were various other teams, including gown-wearing pro bono human rights lawyers and law students, and a small crew coordinating outreach with overseas Taiwanese student groups. Adjacent to them was an art team curating the display of posters behind the podium and assembling new pieces made with donated materials, including a rapidly iterating Democracy Altar directly behind the 
podium, which variously featured temple-style plaques, a pagoda made of cards handdrawn by students from a Tainan girls' high school, and a Guy Fawkes mask. Elsewhere on the main floor was an entire row offered to television news crews who, in the absence of press conferences or other major announcements, would chase after anything that smelled like a story, including dripping air vents. Behind them were food, drink, and sleeping supplies stations. The upstairs mezzanine level was home to a volunteer crew providing live, narrated video feeds of the floor in Chinese, English, and Japanese. Around and in between all these spaces, when not "working," students ate, slept, chatted, read, discussed, and caught up on their studies.

Water, coffee, and crackers donated directly by supporters were carried through the barricades and made freely available throughout the day. Work team volunteers would pick up lunch boxes at regularly announced intervals, and dispose of them in accordance with Taiwan's sophisticated recycling standards. Waste coordination was headed by Mr. Lin, the amiable sixty-six-year-old retired electronics importer who had entered with the first wave of occupiers and quickly earned the affectionate title of Uncle (Abei). "These kids felt right away like my own family. . . . No one else was taking care of clean-up yet, so it just seemed like the right thing to be doing," he said.

\section{The Capital District Reterritorialized as a Microcosm of Civil Society}

As the occupied Legislative Yuan became an administrative center for the ad hoc opposition, with spatial demarcations between work teams, so too did the growing tent city outside subdivide into zones and districts with distinct characters that recapitulated wider Taiwanese social structures. ${ }^{17}$ Underlying support for these temporary districts was provided by expanding security, supply (wuzi), and waste disposal teams who maintained uneven and occasionally strained communications and coordination with each other and with their counterparts inside the Legislative Yuan, who usually stayed behind rows of police and volunteer security.

Directly south of the Legislative Yuan, on Qingdao East Road, was the highestprofile public area, featuring a stage, a public address system, rotating emcees, and a wide and free-flowing variety of speeches and musical performances. A long wall to the south of this new "Town Square" became a sprawling canvas for flyers, posters, and other visual forms of protest. Many of these artifacts were later collected by teams from Taiwan's premiere public research institute, Academia Sinica, both for historical preservation and for use in future curated displays.

Both sides of this central area were flanked by tent and desk zones claimed, staffed, and inhabited by students from universities, including NTU, National Chengchi

\footnotetext{
${ }^{17}$ For a Chinese-language statistical analysis of the backgrounds of the protesters, see the results of a randomly sampled survey conducted on-site by Chen Wan-chi, "Who Joined the 'Student Movement'? A Picture of the Population of the Sunflower Movement," Taiwan Street Corner, http:// twstreetcorner.org/2014/06/30/chenwanchi-2/ (accessed November 14, 2014). For results from an online, post-occupation survey, see Yang Man-yu, "Post-Sunflower Movement Survey: Participants Brought Unexpected Force," http://www.thenewslens.com/post/55004/ (accessed November 14, 2014).
} 
University, and National Taiwan University of the Arts. The relative reputations of these institutions arguably declined with increasing distance from the center. Interspersed between these individual encampments were volunteer-staffed supply, security, and medical stations. With each successive day, water, snacks, sleeping bags, toiletries, and portable toilets became increasingly available free of charge, made possible by donations of both supplies and money routed through affiliated NGOs.

One block south of Qingdao East Road, in the more sprawling encampments on Jinan Road, a motley assortment of activities and activists converged. "It's a Democracy Night Market!" observed Pei-ling, an NTU graduate. Indeed, a few opportunistic profiteers had slipped in to sell politically themed t-shirts and books, but the vast majority of outlets offered free goods and services. These included a "Democracy Cafe," with volunteer professional baristas brewing free-trade beans, and a "Liberty noodles" stand, both serving occupiers free of charge.

Nearby was the self-deprecatingly named Low Life Liberation Zone (jianmin jiefang $q u$ ), populated largely by students who had joined the occupation early but grown disaffected by its increasingly bureaucratic management. The "Low Lifes" experimented with decentered group discussion, singing, and other forms of interaction. Conversations covered everything from the Paris Commune to Taiwan's deferred postcoloniality. Conveners explained that they were not splittists, but that all leaders, even stars like Lin Fei-fan, must still be held accountable. Heated tactical debates dissolved into anything from Chilean revolutionary songs in Mandarin translation, accompanied by drums, guitars, and accordions, to costumed electronic dance parties.

Meanwhile, on Zhongshan South Road, bounding the western edge of the temporary autonomous zone, older pro-independence activists from the Referendum Alliance continued their nearly six continuous years of demonstrations calling for an amendment of Taiwan's "birdcage" referendum law, so-named because the voting threshold is so high that no referendums have been passed since its drafting in 2003 by a KMT-dominated legislature. Largely Taiwanese (Hoklo) speaking, this area became popular in the last days of the occupation as the original site of the "Intestine Flower" (Da Chang Hua) events, in which activists engaged in humorous, profanity-laced vents about their time on the frontlines, which proliferated island-wide even after the occupation ended.

\section{From Occupation to Mass Rally to Exodus}

As both occupiers and the Ma administration refused to budge, Chen Wei-ting and Lin Fei-fan announced a major rally for Sunday, March 30. It turned out to be the largest nonpartisan, pro-democracy rally in Taiwan's history. According to the organizers' count, corroborated by The Diplomat and The Wall Street Journal, at least 350,000 protesters ended up swelling the streets in front of the Presidential Office with songs, speeches, and a call for the nation's elected leadership to listen to demands of the students. Similar, smaller actions were held the same day in solidarity around the world, with images of pro-Sunflower demonstrators in Los Angeles, Tokyo, Paris, Berlin, and beyond shared through live feeds with protesters in and outside the Legislative Yuan. 
However, beyond overseas Taiwanese networks, reportage remained scarce outside of Taiwan. International media attention remained focused on a missing Malaysian plane and a crisis in Ukraine. Instead of waiting for reporters to arrive, activists promoted their cause through new social media outlets, ${ }^{18}$ including an "official" Sunflower Movement Facebook page sharing news in fourteen languages, including English, Chinese, Japanese, Arabic, Polish, and Portuguese, translated by a team both physically sited within the Legislative Yuan and augmented with overseas volunteers. The Facebook page gained over 50,000 "likes" in its first several days, and was quickly linked to an Englishlanguage Sunflower Movement Twitter account and a parallel Japanese-language stream. Other breaking stories were narrated through loosely affiliated new outfits, including Taiwan Voice, a Facebook channel. ${ }^{19}$ Another group 4am.tw, raised enough money from 3,621 donors on Taiwanese crowdfunding site FlyingV to purchase a full-page ad in the New York Times. Quietly undergirding all of these online campaigns was g0v, a group of computer-savvy political activists advocating transparent and flat organization. g0v members entered the Legislative Yuan in the early days of the occupation, took responsibility for maintaining the building's Internet access, and placed video cameras to keep occupiers visible and accountable to the public. These video cameras supported live feeds on the g0v.today website, a sophisticated, collaborative online multimedia workspace, which also included multilingual announcement and meeting transcripts, and discussion forums.

As the Sunflower protests continued, counter-protests were planned. On March 29, the day before the major Sunflower rally, the KMT organized a small "Carnation Movement" rally, asking mothers to tell their children to respect authority and come home. In an almost self-parodic turn, Chang An-le (aka "White Wolf"), the leader of the "Peaceful Reunification Party" and a reputed boss of the Bamboo Union gangster mob who served prison time for felony convictions in the United States, called a press conference expressing support for pro-China government policy and threatening to enter the Legislative Yuan on April 1. Security was tight and tension high that day, with Chang arriving on a truck followed by a 500 -strong team of supporters who were spotted shoving Sunflowers. A telling moment came during Chang's speech: As he yelled, "You don't deserve to be Chinese!" in an attempt to insult the activists, he was answered with smiles and shouts, "We are Taiwanese!"

As the battle continued, both sides showed no signs of compromise. To resolve the crisis, President Ma offered to meet with protest leaders privately in his office, a move that was rebuffed by Lin Fei-fan and Chen Wei-ting, who insisted that such a meeting be open and televised. The impasse was only broken when Legislative Speaker Wang Jin-pyng, flanked by his occasional ally of convenience, DPP legislative leader Ker Chien-ming, visited the Legislative Yuan on April 6 and promised that the CSSTA would not be passed without review and without earlier passage of some kind of cross-strait regulatory supervision mechanism. KMT spokespeople expressed shock and strong criticism of Wang's declaration, which apparently had not been approved by the party. While many students still found Wang's pledge unsatisfactory, a decision to clean up and evacuate the

\footnotetext{
${ }^{18}$ For a detailed general account, see Vincent Y. Chao, "How Technology Revolutionized Taiwan's Sunflower Movement," The Diplomat, April 15, 2014, http://thediplomat.com/2014/04/how-tech nology-revolutionized-taiwans-sunflower-movement/ (accessed November 8, 2014).

${ }^{19}$ Taiwan Voice, https://www.facebook.com/TaiwanVoice (accessed October 23, 2014).
} 
Legislative Yuan on April 10 was soon made in secret by core organizers. Announced the day after Wang's visit, the news stunned many protesters who felt they had not been consulted and did not want to give up their occupation of a major government building, which they saw as their only bargaining chip. "These leaders are just as anti-democratic as the Ma government," said An-ting, an education graduate student, who angrily left the Legislative Yuan upon hearing the news to rejoin the more radical splinter group, the Low Life Liberation Zone. ${ }^{20}$ Before leaving on April 10 in a carefully choreographed march strewn with real-life sunflowers, students cleaned up the space and invited assessors to estimate costs for property repairs. Many meetings took place both inside and outside the Legislative Yuan, including a "civil assembly" on the final day, in an attempt to salve the wounds of disaffected protesters and consolidate support for further action.

\section{Aftermath: A Scattering and Sprouting of the Seeds}

Although the CSSTA was placed on ice, widespread protests continued to rock Taipei even after the occupation ended. As they did during the earlier social movements that hastened Taiwan's democratization and birthed the DPP, police blocked central Taipei streets for the next several weeks with steel and razor wire barriers. On Facebook, this policy was popularly mocked as the Ma administration's "International Barbed Wire Exhibition." Even the 228 Peace Park, a park near the Presidential Office so-named to commemorate the 1947 KMT massacre of Taiwanese civilians, was bisected by the spiked metal barriers.

Activists, still mobilized, quickly turned from the CSSTA to the unsettled issue of Taiwan's fourth nuclear power plant, an unfinished KMT-driven project. Begun in the 1980s, it is sited within 7 kilometers of a major earthquake fault line and has gone through many questionable contractor and design changes. Following the 2011 Fukushima disaster, public opinion turned decisively against the opening of the reactor.

Democracy activist and former DPP chairman Lin Yi-hsiung announced an indefinite hunger strike against the plant's construction, starting on April 22. Coming from an elderly former political prisoner whose twin daughters and mother were murdered while their house was under twenty-four-hour secret police surveillance in 1980, Lin's announcement struck a nerve. Perhaps no one else on the island would have been as effective in rallying support. As his only surviving daughter explained in an interview with Taiwan Voice, Lin was motivated not just about the potential dangers of the plant, but also about democracy — as with the trade pact, the Ma administration was acting contrary to public opinion. ${ }^{21}$ In solidarity with the increasingly frail Lin, young activists, many of whom had been involved in the trade deal protest, occupied the street in front of the Taipei Train Station on the night of April 27. In an echo of the police action several weeks earlier at the Executive Yuan, protesters were dispersed by water cannons and riot police on order of Taipei Mayor Hau Lung-Bin, also a prospective KMT presidential candidate for 2016. However, the following day, the Ma administration capitulated and announced a temporary halt to construction. Lin ended his hunger strike shortly after.

\footnotetext{
${ }^{20}$ This name has been changed.

${ }^{21}$ Taiwan Voice, https://www.facebook.com/TaiwanVoice (accessed November 14, 2014).
} 
Not to be outdone by anti-government protests, KMT-allied forces staged a small counter-protest in front of the Presidential Office on May 4. Calling itself the New May 4th Movement, recalling early twentieth-century Republican-era China's landmark cultural movement, it celebrated the Republic of China and called for "public order." Thus it was all too ironically fitting that Chang An-le, the convicted felon and head of the Peaceful Reunification Party, was again in attendance after leading the April 1 rally in front of the Legislative Yuan.

The seemingly endless series of protests led even The Economist newsmagazine to suggest that, with $\mathrm{Ma}$ a lame duck serving in the absence of a popular mandate, Taiwan's future may be decided on the streets. ${ }^{22}$ However, while direct action seems to have quickly achieved the initial objectives of both the Sunflowers and the overlapping anti-nuclear movement, the centralization and unity of purpose maintained inside the Legislative Yuan occupation and outside during the anti-nuclear street occupation have proven difficult to maintain. The broad base has splintered into several groups, including Taiwan March, led by the most visible Sunflower activists like Lin Fei-fan, Chen Wei-ting, and Huang Kuo-chang, and advocating primarily to lower the voting thresholds for national referendums. Other spinoff groups include Democracy Tautin, convened by Lee Chun-ta and focused on wider grassroots action, and Democracy Kuroshio, a student alliance. Even the Low Life Liberation Zone remained engaged in regular discussion about radical democratic interaction for at least several months after the occupation. Strikingly, none of these groups chose to maintain the "Sunflower" moniker, despite the symbol's wide appeal and high profile. Said Yun during Democracy Tautin's heated naming debate, "We don't feel like a few dozen of us have the right to appropriate the name of a movement of hundreds of thousands. Besides, even though most of the people in our group were inside the occupation from the beginning, we never chose the name Sunflower anyway. The media just started calling us that because of some florist." ${ }^{, 23}$

While the Sunflowers proliferated, splintered, and collaborated, they maintained a sometimes cooperative, sometimes combative dance with the DPP throughout the 2014 midterm elections. The DPP itself emerged from an earlier generation of social activists, but after gaining power, its members were often criticized not only for being out of touch with conditions on the street, but also for being ineffective administrators and campaigners. Some in the leadership took the message to heart. "They [student activists] could probably run a better campaign than the DPP," admitted Tsai Ying-wen, ${ }^{24}$ who emerged as the undisputed DPP chair in the wake of the protests. Several Sunflower activists were soon hired by DPP youth committees and courted by mayoral candidates notably by Taipei’s successful independent candidate, Dr. Ko Wen-je.

Other activists remained cagey, especially as several prominent figures in the DPP renewed their call for the party to freeze the pro-independence plank of its founding

\footnotetext{
${ }^{22}$ See "When the Wind Blows," The Economist, May 3, 2014, http://www.economist.com/news/asia/ 21601553-president-bows-street-protests-against-nuclear-power-when-wind-blows (accessed October 23, 2014).

${ }^{23}$ This name has been changed.

${ }^{24}$ Vincent Y. Chao, "How Technology Revolutionized Taiwan's Sunflower Movement," The Diplomat, April 15, 2014, http://thediplomat.com/2014/04/how-technology-revolutionized-taiwans-sun flower-movement/ (accessed November 8, 2014).
} 
charter. "If they do so," said Chen Wei-ting, "they should prepare to be replaced." ${ }^{25}$ But with the DPP looking strong in the 2016 elections, pragmatic Sunflowers hoping for wide-scale structural change are likely to both pressure and rally around the party and its coalitions.

Even if the integration of the Sunflower activists was difficult to maintain, any doubts about the Movement's alignment with the electorate were put to rest when the KMT suffered a landslide defeat in the "nine in one" midterm local elections on November 29, $2014 .^{26}$ Well-funded KMT mayoral candidates lost their traditional northern strongholds of Taipei, Taoyuan, and Hsinchu, turning the conventional wisdom about Taiwan's political geography on its head. Popular DPP incumbents were handily re-elected in the south. The DPP earned 47.6 percent of the nationwide vote compared to the KMT's 40.7 percent, not including Taipei, which elected an independent tacitly allied with the DPP-led "pan-green" coalition. This has given the opposition party significant momentum for the coming 2016 presidential and legislative elections. Smaller Sunflower-affiliated parties, including the Green Party of Taiwan and the Tree Party, also won their first local seats. ${ }^{27}$

Following the electoral defeat of the KMT, President Ma's dream of a "peace treaty" with China based on the "One China Principle" - that both territories belong to the same country-have likely evaporated. Xi's surprise September reiteration that the "One Country, Two Systems" formulation is the only one acceptable to the PRC did little to help his cause. Especially in light of unrest in Hong Kong, the showcase of the supposedly successful "One Country, Two Systems" scheme, the two leaders' major cross-strait achievement to date may have been not political unification of the two territories, but an inadvertent unification, however temporary, of the Taiwanese independence movements and the democratic left. This has also enabled Taiwanese activists to develop new sympathies and alliances with their counterparts in Hong Kong. ${ }^{28}$

Defying the "realist" analysis that consigned their home to slow, quiet takeover just weeks before the occupation, not only do Taiwanese appear to be saying goodbye ever more loudly to "peaceful reunification," but many people in Hong Kong are as well. Between October and December 2014, Hong Kong student and civic activists conducted unprecedented pro-democracy protests, which included occupation of central government and commercial districts. Ultimately, the Umbrella Movement, a response to similar

\footnotetext{
${ }^{25}$ Chen Hui-ping and Jake Chung, "Ex-DPP Legislator Seeks Independence Clause’s Freezing," Taipei Times, June 20, 2014, http://www.taipeitimes.com/News/front/archives/2014/06/20/2003 593198 (accessed November 14, 2014).

${ }^{26}$ Min-hua Huang, "Taiwan's Changing Political Landscape: The KMT's Landslide Defeat in the Nine-in-One Elections," Brookings East Asia Commentary, December 2014, http://www. brookings.edu/research/opinions/2014/12/08-taiwan-political-landscape-elections-huang (accessed December 18, 2014).

${ }^{27}$ Lii Wen, “2014 ELECTIONS: Smaller parties clinch big victories", Taipei Times, December 1, 2014, http://www.taipeitimes.com/News/taiwan/archives/2014/12/01/2003605715 (accessed December 18, 2014).

${ }^{28}$ While the SAR's Occupy Central demonstrations were planned separately, grounds for collaboration were accelerated when several Hong Kong activists visited the occupied Legislative Yuan. Several Sunflower leaders attempted to visit Hong Kong in late June 2014 to join meetings and conferences. Their applications for entry permits to the territory were rejected without explanation.
} 
concerns that employed similar tactics, resembled, ${ }^{29}$ outscaled, and outlasted the Sunflower Movement, even if it did not win policy concessions or disperse on its own terms.

At the beginning of the movement, after peaceful demonstrators were met with police tear gas on September 28, Taiwanese activists, including Chen Wei-ting, stormed the Hong Kong trade office in Taipei, decrying police brutality and demanding a halt to all talks with China, and they and 1989 Tiananmen protest veterans staged sudden demonstrations in Liberty Square. Said Lau Ka-yee, a women's rights activist from Hong Kong, speaking to the crowd, "Taiwanese often say that today's Hong Kong will be tomorrow's Taiwan. However, I think: 'Today's Hong Kong is today's Taiwan' is closer to the truth. People need to gain a sense of urgency.,30 Many Taiwanese flew in to demonstrate in solidarity, ${ }^{31}$ and Hong Kong activists expressed their support for Taiwan's social movements. "If this doesn't work, maybe we'll try to immigrate to Taiwan," was a half-serious refrain I heard from many Umbrella Movement activists after I arrived in Hong Kong on September 30. Given the Sunflower Movement's still uncertain influence on Taiwan's relationship with China, what kind of Taiwan they might emigrate to remains to be seen.

Meanwhile, to the north lies a Japan uneasy about China's rise, and to the east, a United States still figuring out how Obama's "pivot to Asia" strategy may articulate in a cross-strait context. Two of the other keys to Taiwan's geopolitical future, they and the Chinese leadership watch with bated breath as the seeds of the Sunflower Movement sprout in an increasingly vibrant, volatile, and re-networked region.

\section{A Note on Images}

Scenes from inside and around the occupied Legislative Yuan. Blocked chamber doors, student teams at "work," police and legislators with little to do, impromptu press conferences, free food and coffee vendors, musical marches, and free speech zones. All pictures taken by the author.

\section{Acknowledgments}

This article is dedicated to the activists and analysts who shared their insights and care, to the police and politicians who helped keep relative peace while under great pressure, and to the memory of Oliver Chen, the National Taiwan University law student and Sunflower translation and media team lead who passed away as this article was being completed. Thanks are due to the Fulbright Program, the Foundation for Scholarly Exchange, and the Institute of Sociology at Academia Sinica for affiliation and support during the research period.

\footnotetext{
${ }^{29}$ Ian Rowen, “A Tale of Sunflowers and Umbrellas," Thinking Taiwan, October 3, 2014, http:// thinking-taiwan.com/tale-of-sunflowers-and-umbrellas/ (accessed November 14, 2014).

${ }^{30}$ Lii Wen, "Protesters Storm HK Office in Taipei in a Display of Solidarity," Taipei Times, September 30, 2014, http://www.taipeitimes.com/News/front/archives/2014/09/30/2003600906 (accessed November 14, 2014).

${ }^{31}$ Cindy Sui, "Why Taiwan Is Watching Hong Kong Protests," BBC, September 30, 2014, http:// www.bbc.com/news/world-asia-29422233 (accessed November 14, 2014).
} 


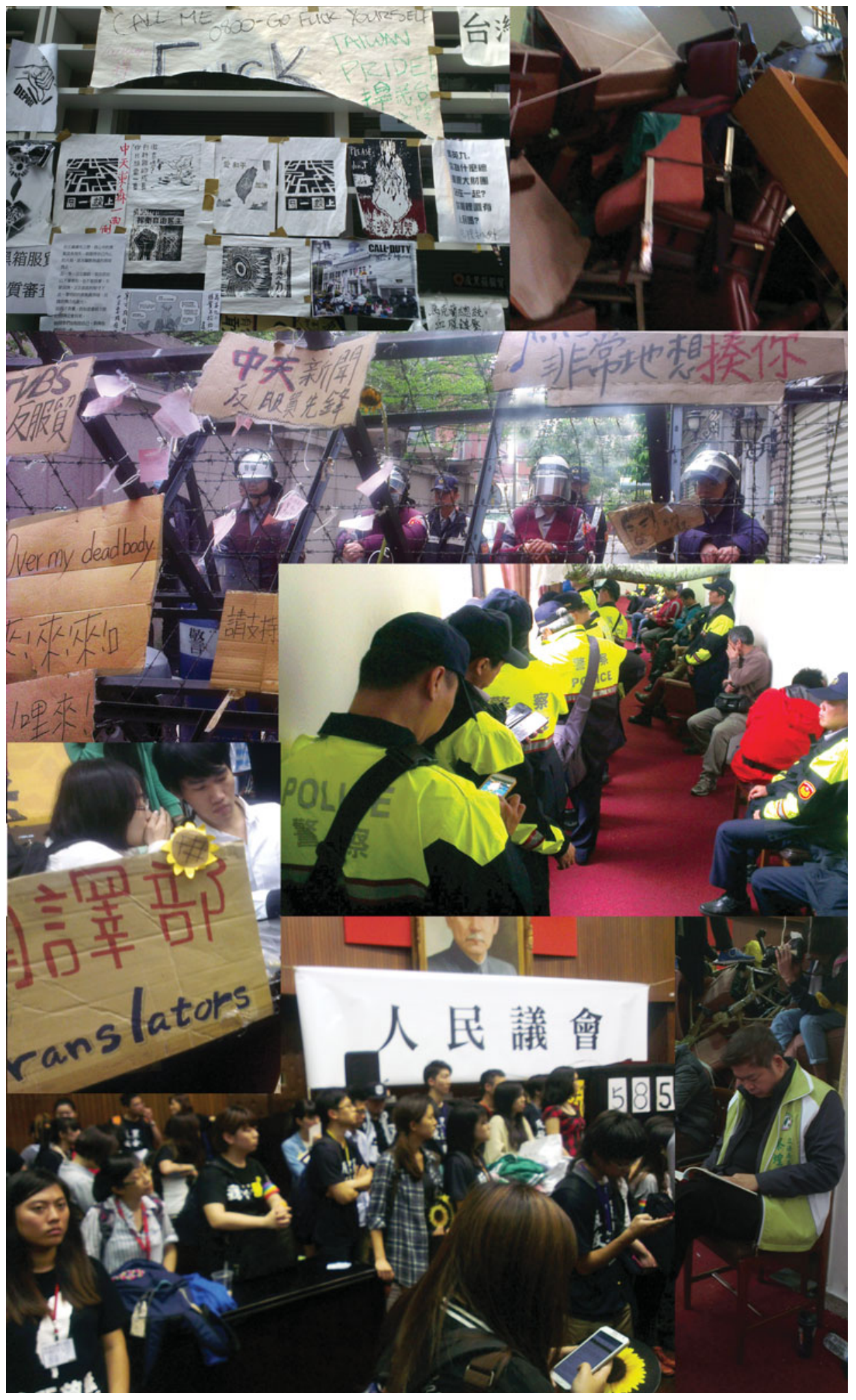




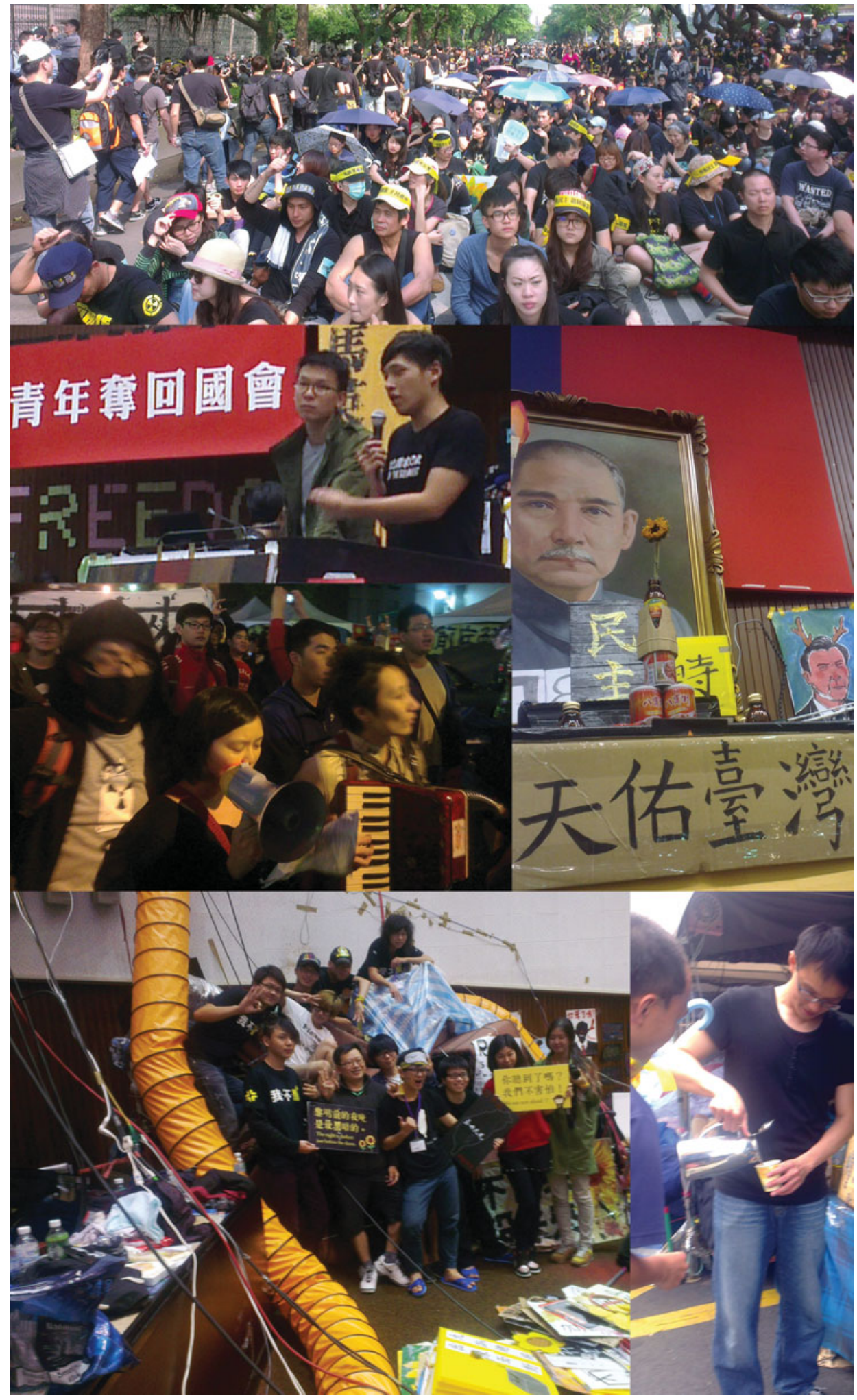

